\title{
Variability of topsoil properties at the southern coast of Finland and the number of soil samples needed for the estimation of soil properties
}

\author{
RAILI JOKINEN
}

University of Helsinki, Department of Agricultural Chemistry, Sf-00710 Helsinki 71, Finland

Abstract: A total of 430 topsoil samples were collected from ten fields of the Viikki Experimental Farm, University of Helsinki. Particle size distribution, organic carbon content, $\mathrm{pH}\left(\mathrm{CaCl}_{2}\right)$, exchangeable $\mathrm{Ca}, \mathrm{Mg}, \mathrm{K}$ contents, plant available $\mathrm{P}($ Bray 1$), 1 \mathrm{M} \mathrm{KCl}$ extractable $(\mathrm{Al}+\mathrm{H})$ content and effective cation exhange capacity of the soils were determined.

The coefficient of variation was used as indicator of the variability of soil properties within each field. The lowest coefficients of variation were observed for $\mathrm{pH}\left(\mathrm{CaCl}_{2}\right)$ and the highest for exchangeable $\mathrm{Mg}$ $1 \mathrm{M} \mathrm{KCl}$ extractable $(\mathrm{Al}+\mathrm{H})$ and effective cation exchange capasity.

The results indicate that from $1\left(\mathrm{pH}\left(\mathrm{CaCl}_{2}\right)\right)$ to 33 (exchangeable $\mathrm{Mg}$ ) samples per hectare are needed from individual fields for strict level of accuracy in estimation of the soil properties. For determination of soil type (according to clay content) and organic carbon content on average 8 samples, and for the plant available $\mathrm{P}$ (Bray 1) and exchangeable $\mathrm{Mg}$ and $\mathrm{K}$ contents 10 to 16 samples per hectare appear sufficient. Four samples suffice for a less stringent, lax accurate determination of all properties.

The variability of soil properties is discussed from the viewpoint of agricultural advisory work and field experiments for agricultural research.

\section{Introduction}

As early as 1935 KIVINEN drew attention to the grat variability in the chemical properties of soil even within the space of 30 or 40 metres. This he found to cause wide variations in the yields of the reference variety in a field experiment. KAILA and RYTI (1951) studied soil samples taken at distances of 2 metres and distances of 25 centimetres, concluding that it is difficult to obtain really representative samples for the estimation of soil properties. In a review article BECKETT and WEBSTER (1971) noted about 80 studies dealing with the variability of the properties of agricultural and forest soils. The subject has since been re-investigated in connection, for example, with regulation of nitrogen fertilization of farmland (LINDÉN 1979), forest management (QUESNEL and LAVKULICH 1980) and prediction of timber yields (BLYTH and MACLEOD 1978). 
The aim of this study was to clarify the variability in soil properties as these may affect the interpretation of results obtained in field experiments and the recommendation made in the course of agricultural advisory work. The number of soil samples needed for accurate estimation of the properties is calculated.

\section{Materials and methods}

The material of the study consists of topsoil samples collected from the agricultural area of the Viikki Experimental Farm (University of Helsinki). This farm is situated near the Gulf of Finland. The geography of the fields is rather flat. In the soil profiles there appears strata with considerable differences in the particle size distribution originating in the time of deposition.

After harvestings of the crops, in September 1979 and 1981, the fields were marked with lines 40 metres apart, along which soil samples (volume 2 litres) representing the plough layer were taken at 40-metre intervals. Ten fields were sampled as follows:

\begin{tabular}{lccc}
\hline $\begin{array}{l}\text { Field } \\
\text { number }\end{array}$ & $\begin{array}{c}\text { Area } \\
\text { ha }\end{array}$ & $\begin{array}{c}\text { Number of } \\
\text { samples }\end{array}$ & Samples/ha \\
\hline 49 & 7.27 & 45 & 6.2 \\
54 & 17.18 & 99 & 5.8 \\
84 & 8.21 & 42 & 5.1 \\
86 & 7.37 & 46 & 6.2 \\
88 & 5.22 & 34 & 6.5 \\
89 & 5.28 & 31 & 5.9 \\
94 & 1.08 & 6 & 5.6 \\
96 & 10.29 & 66 & 6.4 \\
97 & 3.60 & 23 & 6.5 \\
98 & 5.82 & 38 & \\
Total & 71.32 & 430 & \\
\hline
\end{tabular}

About one third of the Viikki area of 232 ha was sampled (Fig. 1). For the minor part the fields number 54,84 and 86 were at the time under fields experiments, no fertilization experiments.

The samples were kept on laboratory tables until they reached air-dry state, after which they were crushed to pass through a $2 \mathrm{~mm}$-sieve. The properties of the soils were determined by the following methods:

- $\mathrm{pH}$ in $0.01 \mathrm{M} \mathrm{CaCl}_{2}$ suspension, soil to solution ratio 1:2.5 (v/v), equilibration time 4 hours. The material was classified into four groups, where the $\mathrm{pH}\left(\mathrm{CaCl}_{2}\right)$ value was $3.5-4.4,4.5-5.4,5.5-6.4$ and $>6.5$.

- organic carbon, by wet combustion with $\mathrm{K}_{2} \mathrm{Cr}_{2} \mathrm{O}$, and $\mathrm{H}_{2} \mathrm{SO}_{4}$ (conc.) and thereafter colorimetric determination. On the basis of the organic carbon content the mineral soils were classified into three groups of $1.7-3.4 \%, 3,5-6.9 \%, 7.0-11.5 \%$. The soils with organic carbon content $11.6-23.2 \%$ are mull soils.

- particle sizes were determined by pipette method (ELONEN 1971). Soils where the clay $(<2 \mu \mathrm{m})$ content is less than $30 \%$ are non-clay soils. In the total material there were 179 samples of fine sand soils, 21 samples of finer fine sand, 226 samples of sandy clay soils. The number of soil samples in the different groups defined by clay content, $\mathrm{pH}\left(\mathrm{CaCl}_{2}\right)$ and organic carbon content are presented in Table 1. 


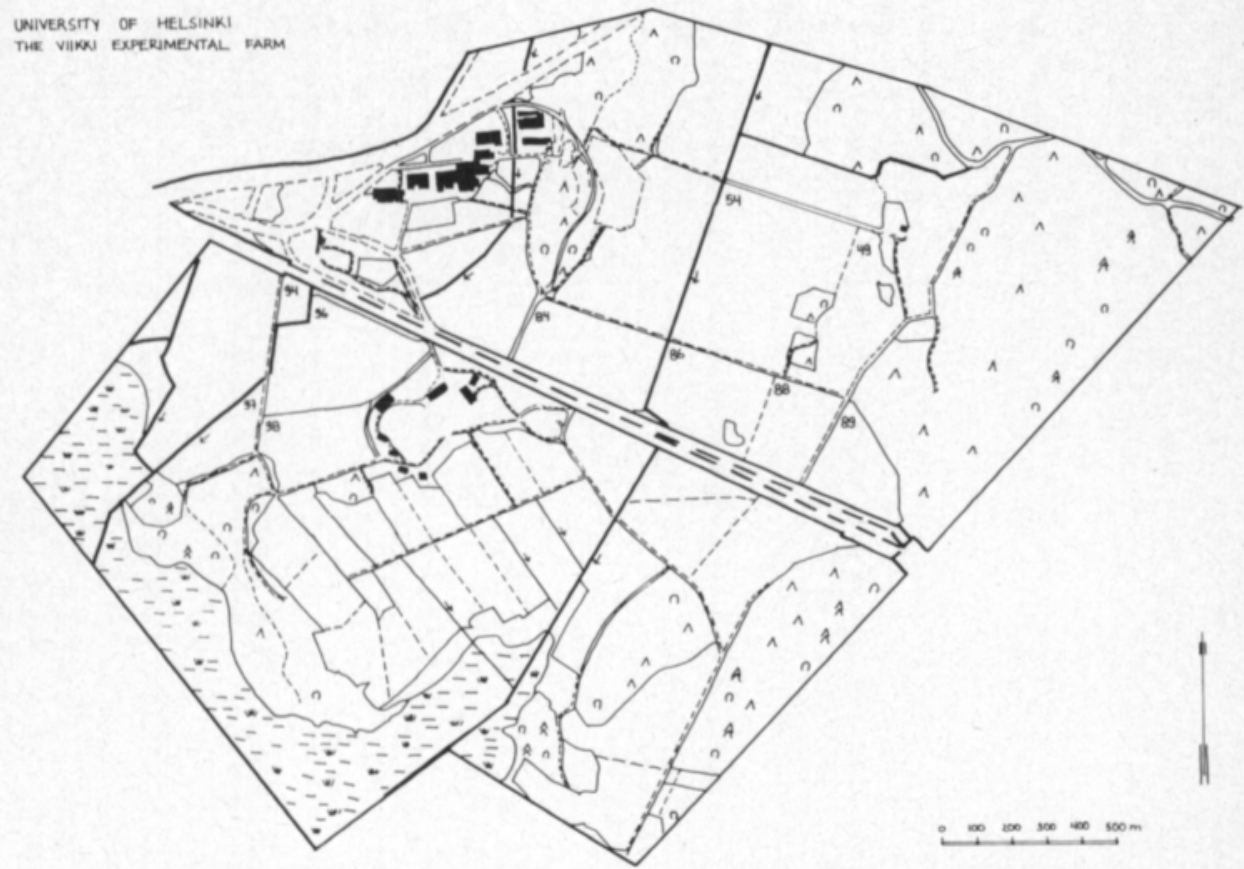

Fig. 1. Field layout of the Viikki Experimental Farm, University of Helsinki.

- the exchangeable cations were extracted with $1 \mathrm{M}$ neutral ammonium acetate. Calcium and magnesium were determined by atomic absorption spectrophotometry (Varian Techtron 100 ), with interference Sr and exchangeable $\mathrm{K}$ by flame photometry (Lange).

- the exchange acidity $(\mathrm{Al}+\mathrm{H})$ was displaced with $1 \mathrm{M} \mathrm{KCl}$ and titrated with $0.01 \mathrm{M} \mathrm{NaOH}$.

- the effective cation exhange capasity (ECEC) was determined as the sum of $(\mathrm{Ca}+\mathrm{Mg})$ and $(\mathrm{Al}+\mathrm{H})$ extractable in $1 \mathrm{M} \mathrm{KCl}$ (KAILA 1971).

- the plant available form of soil phosphorus was extracted with $0.03 \mathrm{M} \mathrm{NaF}+0.025 \mathrm{M} \mathrm{HCl}$ by the Bray 1 test (BRAY and KURTZ 1945) modified by KAILA (1965) and determined by molybdenum blue method.

The mean $(\overline{\mathrm{x}})$, standard deviation $(\mathrm{s})$ and coefficient of variation in per cent $(\mathrm{v})$ of the soil properties were calculated for each of the ten fields. The number of samples needed for accurate determination of the soil properties was calculated according to SNEDECOR (1948) by the equation $n=\frac{t^{2} v^{2}}{p^{2}}$, where $n=$ number of samples needed, $\mathrm{t}^{2}=$ square of Students $\mathrm{t}, \mathrm{v}^{2}=$ square of coefficient of variation, and $\mathrm{p}=$ allowable error in per cent. The number of samples needed was calculated both with $t=5 \%, p=10 \%$ (strict level of accuracy $=\mathrm{n}_{1}$ ) and with $\mathrm{t}=10 \%, \mathrm{p}=25 \%$ (lax level of accuracy $=\mathrm{n}_{2}$ ).

\section{Results}

Except in field 54 only one crop was grown in each field, so that fertilization was the same over the whole field. On field 54 two different crops were grown, in both sampling years. Within a field main reason for the variation should then be the inherent heterogeneity of soil properties and the cultivation history. 
Table 1 The number of soil samples in different classes of clay content, $\mathrm{pH}\left(\mathrm{CaCl}_{2}\right)$ and organic carbon content in ten fields.

\begin{tabular}{|c|c|c|c|c|c|c|c|c|c|c|}
\hline & \multicolumn{10}{|c|}{ Number of soil samples } \\
\hline & \multicolumn{10}{|c|}{ Field number } \\
\hline & 49 & 54 & 84 & 86 & 88 & 89 & 94 & 96 & 97 & 98 \\
\hline \multicolumn{11}{|l|}{ Clay, \% } \\
\hline$<30$ & 38 & 83 & 19 & 17 & 17 & 4 & & 2 & 7 & 13 \\
\hline $30-60$ & 7 & 15 & 23 & 26 & 17 & 27 & 6 & 64 & 16 & 25 \\
\hline$>60$ & & 1 & & 3 & & & & & & \\
\hline \multicolumn{11}{|c|}{ Org. C, \% } \\
\hline $1.7-3.4$ & 18 & 39 & 3 & 21 & 11 & & & 1 & 3 & 15 \\
\hline $3.5-6.9$ & 22 & 47 & 39 & 25 & 20 & 7 & 2 & 28 & 9 & 21 \\
\hline $7.0-11.5$ & 2 & 13 & & & 3 & 23 & 3 & 37 & 11 & 2 \\
\hline $11.6-23.2$ & 3 & & & & & 1 & 1 & & & \\
\hline \multicolumn{11}{|l|}{$\mathrm{pH}\left(\mathrm{CaCl}_{2}\right)$} \\
\hline $3.5-4.4$ & & & & & 3 & & 1 & 1 & 7 & 3 \\
\hline $4.5-5.4$ & 7 & 41 & 29 & 14 & 30 & 27 & 5 & 52 & 16 & 22 \\
\hline $5.5-6.4$ & 29 & 54 & 12 & 32 & 1 & 4 & & 12 & & 12 \\
\hline $6,5-$ & 9 & 4 & 1 & & & & & 1 & & 1 \\
\hline
\end{tabular}

The coefficient of variation of $\mathrm{pH}\left(\mathrm{CaCl}_{2}\right)$ was between 5.4 and $10 \%$ in the individual fields (Table 2). The difference between maximum and minimum $\mathrm{pH}\left(\mathrm{CaCl}_{2}\right)$ values in a single field was at the lowest 1.0 unit (field 97) and at the highest 2.3 units (field 98). The distance between the extreme values in field 98 was about 170 metres. In the field 49 the $\mathrm{pH}\left(\mathrm{CaCl}_{2}\right)$ values for the two adjacent points (distance apart 40 metres) with greatest difference in value were 6.1 and 4.9. Were the $\mathrm{pH}\left(\mathrm{CaCl}_{2}\right)$ of the soil to be adopted as the indicator of the liming requirement, the minimum, maximum and mean values would indicate the addition of three different amounts of liming agents.

Because the $\mathrm{pH}$ scale is logarithmic the coefficient of variation of $\mathrm{pH}\left(\mathrm{CaCl}_{2}\right)$ is not comparable to the coefficients for other soil properties.

The range in the organic carbon content was widest in field 49 from 1.8 to $14.6 \%$ (Table 3) and the coefficient of variation was highest there too (Table 2). As high carbon contents were observed in field 94 as in field 49 , but the material was concentrated near the mean and the coefficient of variation remained low. The change in carbon content in field 49 occurred gradually, unlike $\mathrm{pH}\left(\mathrm{CaCl}_{2}\right)$. The great differences in organic carbon content cause differences in the water and nutrient retention capacity of the soil and can lead to uneven maturity of the crops.

The range of the clay content was especially wide in fields 54 and 86 (Table 3). In field 54 the clay content changed within a distance of 100 metres from 11 to $65 \%$ and the fine sand content from 76 to $17 \%$. In field 86 the distance between minimum and maximum clay contents (7 and $62 \%$ ) was 
Table 2. The coefficient of variation $(v \%)$, the number of soil samples needed for the strict $\left(\mathrm{n}_{1}\right)$ and lax $\left(\mathrm{n}_{2}\right)$ level of accuracy in determination of soil properties in the individual fields, and the average values (field 94 omitted).

\begin{tabular}{|c|c|c|c|c|c|c|c|c|c|c|c|c|}
\hline & $v \%$ & $\mathrm{n}_{1}$ & $\mathrm{n}_{2}$ & $v \%$ & $\mathrm{n}_{1}$ & $\mathrm{n}_{2}$ & $v \%$ & $\mathrm{n}_{1}$ & $\mathrm{n}_{2}$ & $v \%$ & $\begin{array}{ll}\mathrm{n}_{1} & \mathrm{n}\end{array}$ & $\mathrm{n}_{2}$ \\
\hline & \multicolumn{3}{|c|}{$<2 \mu \mathrm{m}, \%$} & \multicolumn{3}{|c|}{$2-20 \mu \mathrm{m}, \%$} & \multicolumn{3}{|c|}{$20-200 \mu \mathrm{m}, \%$} & \multicolumn{3}{|c|}{ Org. C, \% } \\
\hline 49 & 49.5 & 14 & 1,5 & 43.8 & 11 & 1.2 & 16.9 & 2 & 0.2 & 62.2 & 22 & 2.4 \\
\hline 54 & 52.4 & 6 & 0.7 & 32.2 & 2 & 0.3 & 21.9 & 1 & 0,1 & 40.0 & 4 & 0.4 \\
\hline 84 & 21.2 & 2 & 0.2 & 21.9 & 2 & 0.3 & 19.8 & 2 & 0.2 & 17.4 & 2 & 0.2 \\
\hline 86 & 42.7 & 10 & 1.1 & 29.5 & 5 & 0.5 & 33.1 & 6 & 0.7 & 16.7 & 2 & 0.2 \\
\hline 88 & 40.5 & 13 & 1.4 & 30.4 & 7 & 0.8 & 25.8 & 5 & 0.6 & 37.8 & 11 & 1.3 \\
\hline 89 & 20.1 & 3 & 0.4 & 16.5 & 2 & 0.2 & 21.4 & 4 & 0.4 & 22.2 & 4 & 0.4 \\
\hline 94 & 16.9 & 16 & 1.6 & 26.9 & 40 & 0.4 & 12.5 & 9 & 0.9 & 38.8 & 99 & 8.4 \\
\hline 96 & 11.2 & 1 & 0.1 & 11.9 & 1 & 0.1 & 16.3 & 1 & 0.1 & 18.6 & 1 & 0.1 \\
\hline 97 & 30.6 & 11 & 1.2 & 34.5 & 14 & 1.6 & 44.8 & 24 & 2.6 & 32.8 & 13 & 1.4 \\
\hline 98 & 34.0 & 8 & 0.9 & 22.0 & 3 & 0.4 & 32.3 & 7 & 0.8 & 39.0 & 11 & 1.2 \\
\hline \multirow[t]{2}{*}{ Average } & 31.9 & 8.4 & 0.9 & 27.0 & 5.2 & 0.6 & $24 . .5$ & 5.8 & 0.6 & 32.6 & 7.8 & 0.8 \\
\hline & \multicolumn{3}{|c|}{$\mathrm{pH}\left(\mathrm{CaCl}_{2}\right)$} & \multicolumn{3}{|c|}{$\mathrm{Ca} \mathrm{mg} / \mathrm{kg}$} & \multicolumn{3}{|c|}{$\mathrm{Mg} \mathrm{mg} / \mathrm{kg}$} & \multicolumn{3}{|c|}{$\mathrm{K} \mathrm{mg} / \mathrm{kg}$} \\
\hline 49 & 10.0 & 0.5 & 0.1 & 31.3 & 5 & 0.6 & 56.9 & 18 & 2.0 & 64.0 & 23 & 2.5 \\
\hline 54 & 8.9 & 0.2 & 0.0 & 25.0 & 1 & 0.2 & 79.7 & 15 & 1.6 & 53.9 & 7 & 0.7 \\
\hline 84 & 7.6 & 0.2 & 0.0 & 20.0 & 2 & 0.2 & 38.8 & 7 & 0.8 & 36.0 & 6 & 0.7 \\
\hline 86 & 5.4 & 0.2 & 0.0 & 28.5 & 4 & 0.5 & 58.0 & 19 & 2.1 & 29.8 & 5 & 0.5 \\
\hline 88 & 8.2 & 0.5 & 0.1 & 20.9 & 3 & 0.4 & 41.9 & 14 & 1.5 & 30.3 & 7 & 0.8 \\
\hline 89 & 6.0 & 0.2 & 0.0 & 15.9 & 2 & 0.2 & 24.8 & 5 & 0.5 & 64.2 & 32 & 3.6 \\
\hline 94 & 8.3 & 5.0 & 0.5 & 42.4 & 100 & 10.0 & 29.4 & 48 & 4.8 & 48.3 & 130 & 13.0 \\
\hline 96 & 9.8 & 0.3 & 0.0 & 24.4 & 2 & 0.3 & 41.6 & 7 & 0.7 & 26.4 & 3 & 0.3 \\
\hline 97 & 7.1 & 0.6 & 0.1 & 17.9 & 4 & 0.4 & 52.3 & 33 & 3.6 & 38.9 & 18 & 2.0 \\
\hline 98 & 9.4 & 0.6 & 0.1 & 22.5 & 4 & 0.4 & 59.9 & 25 & 2.8 & 39.2 & 11 & 1.2 \\
\hline \multirow[t]{2}{*}{ Average } & 8.1 & 0.4 & 0.1 & 24.9 & 3.0 & 0.4 & 48.3 & 15.9 & 1.7 & 43.1 & 12.4 & 1.4 \\
\hline & \multicolumn{3}{|c|}{$\mathrm{P}$ (Bray 1$) \mathrm{mg} / \mathrm{kg}$} & \multicolumn{3}{|c|}{$(\mathrm{Al}+\mathrm{H}) \mathrm{me} / \mathrm{kg}$} & \multicolumn{3}{|c|}{ ECEC $\mathrm{mg} / \mathrm{kg}$} & & & \\
\hline 49 & 59.8 & 20 & 2.2 & 141.4 & 111 & 12.4 & 30.4 & 5 & 0.6 & & & \\
\hline 54 & 38.6 & 3 & 0.4 & 68.3 & 11 & 1.2 & 25.7 & 2 & 0.2 & & & \\
\hline 84 & 36.2 & 7 & 0.7 & 66.7 & 22 & 2.4 & 14.9 & 1 & 0.1 & & & \\
\hline 86 & 41.2 & 9 & 1.0 & 33.3 & 6 & 0.7 & 30.7 & 5 & 0.6 & & & \\
\hline 88 & 33.0 & 9 & 1.0 & 78.6 & 35 & 3.9 & 226.5 & $406 ?$ & 32.1 & & & \\
\hline 89 & 28.9 & 7 & 0.7 & 60.0 & 28 & 3.1 & 13.8 & 1 & 0.2 & & & \\
\hline 94 & 58.9 & 193 & 19.3 & 61.1 & 207 & 20.8 & 133.3 & 988 & 99.1 & & & \\
\hline 96 & 50.9 & 10 & 1.1 & 50.9 & 10 & 1.1 & 72.7 & 21 & 2.3 & & & \\
\hline 97 & 35.1 & 15 & 1.6 & 35.2 & 15 & 1.6 & 64.0 & 49 & 5.3 & & & \\
\hline 98 & 42.8 & 13 & 1.4 & 43.0 & 13 & 1.4 & 122.2 & 1051 & 11.6 & & & \\
\hline Average & 42.5 & 10.3 & 1.1 & 63.9 & 27.9 & 3.1 & 73.4 & $158 \quad 1$ & 15.2 & & & \\
\hline
\end{tabular}

about 90 metres. The change in the soil type from fine sand to heavy clay cannot be without effect on the cation content of the soil and on the fertilizer requirement.

The coefficient of variation in particle size distribution, in the amounts of clay, silt or fine sand fractions, were below $50 \%$ except for field 54 (Table 2). In field 96 the coefficient of variation in clay content was low $(11 \%)$, since there sandy clay samples accounted for 64 out of the total 66 samples. 
Table 3. The mean value, standard deviation $(\overline{\mathbf{x}} \pm s)$ and range for soil properties of individual fields.

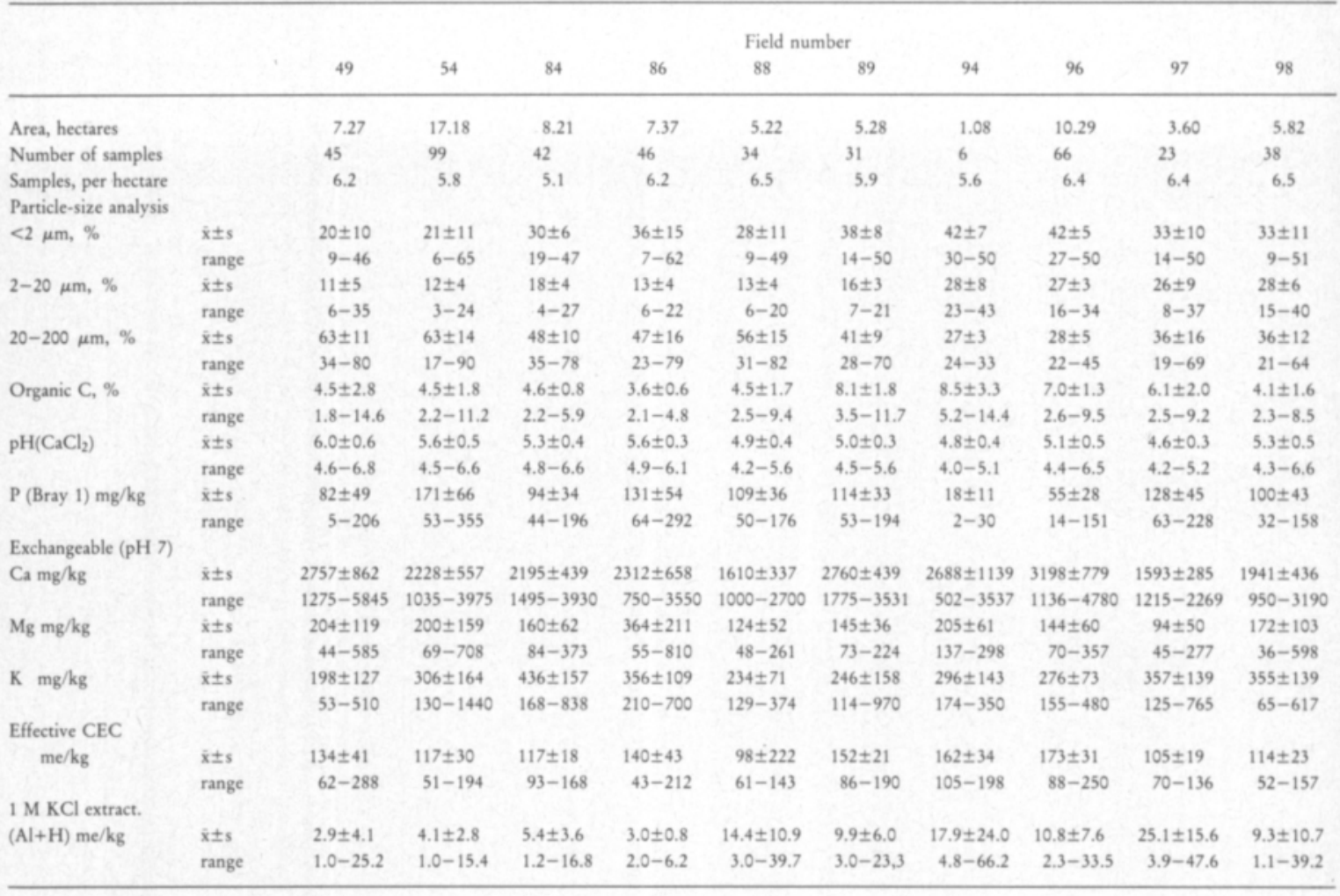

In the $\mathrm{P}$ (Bray 1) content, exchangeable $\mathrm{Mg}$ and $\mathrm{K}$ contents, $(\mathrm{Al}+\mathrm{H})$ content and ECEC the coefficients of variation were over $30 \%$ for almost all fields. Exceptionally high coefficients of variation were recorded for ECEC in three fields. The range of these properties was not widest in the same field for which the greatest coefficients of variation were observed. In the fields where the coefficient of variation in the exchangeable $\mathrm{Mg}$ was high there was also high in clay content. The coefficient of variation in the exchangeable $\mathrm{Ca}$ remained below $30 \%$ extcept in fields $49(31 \%)$ and $94(42 \%)$.

The number of soil samples per hectare needed to satisfy the strict $\left(n_{1}\right)$ and lax $\left(\mathrm{n}_{2}\right)$ accuracy classes as defined above was calculated separately for each field. (Field 94 was omitted because of its small area). In general, $n_{1}$ for $\mathrm{pH}\left(\mathrm{CaCl}_{2}\right)$ was less than one sample per hectare. For the determination of the soil type according to the clay content $\mathrm{n}_{1}$ was between 2 and 16 samples and for $\mathrm{n}_{2}$ about one sample.

For strict level of accuracy in determination of the organic carbon content the number of soil samples needed was between 2 and 22, and for lax level of accuracy about one sample per hectare.

Determinations of the exchangeable $\mathrm{K}$ and $\mathrm{Mg}$ contents with the strict critetion of accuracy demaded from 3 to 32 and from 5 to 33 samples per hectare, respectively. For the determination of the plant-available P content the number of soil samples demanded varied from 3 to 20 and for the 
exchangeable $\mathrm{Ca}$ content from one to five with the strict criterion of accuracy. Lax accurate determination of the nutrient contents could be saticfied by a collection of one $(\mathrm{Ca})$ to four $(\mathrm{K}$ and $\mathrm{Mg}$ ) samples. Because both low and high coefficients of variations were found for $1 \mathrm{M} \mathrm{KCl}$ extractable $(\mathrm{Al}+\mathrm{H})$ and ECEC, the number of soil samples needed for lax accurate determination varied from 0.1 to 32 per hectare.

For the determination of soil type and organic carbon content with the strict accuracy criterion on average 8 soil samples per hectare was found necessary. Correspondingly the determinations of plant available $\mathrm{P}$ and exchangeable $\mathrm{Mg}$ and $\mathrm{K}$ demanded 10 and 16 samples, respectively.

\section{Diskussion}

The 430 topsoil samples collected from the Viikki Experimental Farm represented mainly mineral soils. The mean $\mathrm{pH}\left(\mathrm{CaCl}_{2}\right)$ was near the average value of Finnish mineral soils (SIPPOLA and TARES 1978), considering that $\mathrm{pH}\left(\mathrm{H}_{2} \mathrm{O}\right)=0.5+\mathrm{pH}\left(\mathrm{CaCl}_{2}\right)$ (RYTI 1965). The exchangeable $\mathrm{Ca}$ and $\mathrm{K}$ contents were higher than the average values reported for Finnish mineral soils by KAILA (1973) and SIPPOLA and TARES (1978), while the exchangeable $\mathrm{Mg}$ content does not deviate from the values of the same authors. the ECEC's are likewise in good accordance with an earlier study (KAILA 1971). The plant-available $\mathrm{P}$ contents are higher than the contents reported by KAILA (1965) using the same method probably because of the heavy phosphorus fertilization in the sixties and seventies. The drilling of fertilizers may also cause some differences in the nutrient contents of soil samples taken between rows and along the rows. This effect was probably slight in the present study, however, since samples were taken in the autumn after the harvesting of the crops (URVAS and JUSSILA 1979).

The variability in soil properties was studied in ten fields, revealing a wide range in all the soil properties in individual fields. The ranges obtained by KAILA and RYTI (1951) within 100 square metres and within 1 square metre were slightly narrower than in this material within 1 to 17 hectares. The size of the sampling area apparently has little effect of the ranges found in the soil properties (HEMINGWAY 1955).

The coefficients of variation observed by BALL and WILLIAMS (1968) for uncultivated and unfertilized soils in North Wales were almost the same as in this study for cultivated and fertilized soils. Likewise they reported the highest coefficient of variation for the exchangeable cation contents.

For the present agricultural advisory work in Finland about 1.5 soil samples are collected per hectare (KURKI 1982). In this study one to two samples were found adeqaute for strict accurate determination only of $\mathrm{pH}\left(\mathrm{CaCl}_{2}\right)$. The number of soil samples should be decided according to the most variable property, which in this material was the exchangeable $\mathrm{Mg}$ content. Even for the lax accurate determination 4 soil samples per hectare 
were needed. LINDÉN (1979) suggested collecting about 10 soil samples and for field experiments (LINDÉN 1981) 14 cores per plot (108 square metres).

When field experiments are being laid out the determination of soil properties in advance is important, and the number of soil samples should rather be too high than too low. Several soil samples, each collected from a different sampling point, are more informative than a single sample made up of subsamples from different sampling points. Too little attention has thus far been paid to the density and mode of sampling.

\section{References}

BALL, D. F. \& WILLIAMS, W. M. 1968. Variability of soil chemical proporties in two uncultivated brown earths. J. Soil Sci. 19: 379-391.

BECKETT, P. H. T. \& WEBSTER, R. 1971. Soil variability: A review. Soils Fertil. 34: 1-15.

BLYTH, J. F. \& MACLEOD, D. A. 1978. The significance of soil variability for forest soil studies in north-east Scotland. J. Soil Sci. 29: 419-430.

BRAY, R. H. \& KURTZ, L. T. 1945. Determination of total, organic and available forms of phosphorus in soils. Soil Sci. 59: 39-45.

ELONEN, P. 1971. Particle-size analysis. Acta Agric. Fenn. 122: 1-122.

HEMINGWAY, R. G. 1955. Soil sampling errors and advisory analysis. J. Agric. Sci. 46: 1-8.

KAILA, A. 1965. Some phosphorus test values and fractions of inorganic phosphorus in soils. J. Scient. Agric. Soc. Finl. 37: 175-185.

- 1971. Effective cation-exchange capacity in Finnish mineral soils. J. Scient. Agric. Soc. Finl. 43: 178-186.

- 1973. Calcium, magnesium and potassium in mineral soils from southern half of Finland. J. Scient. Agric. Soc. Finl. 45: 254-261.

- \& RYTI, R. 1951. Observations on factors influencing the results of chemical soil tests. Acta Agric. Scand. 1: 271-281.

KIVINEN, E. 1935. Über die Ungleichmässigkeit des Ackerbodens. J. Scient. Agric. Soc. Finl. 7: 1-17.

KURKI, M. 1982. Suomen peltojen viljavuudesta III. Summary: On the fertility of Finnish tilled fields in the light of investigations of soil fertility carried out in the years 1955-1980. 181 p. Helsinki.

LINDÉN, B. 1979. Kvävegödsling baserad på bestämning av mineralkväveförrådet i marken. Längesrapport om N-prognosverksamhet i några europeiska länder och i Nordamerika. Summary: Nitrogen fertilization recommmendations based on determination of mineral nitrogen in soils. Research and extension facilities for $\mathrm{N}$-prognosis in some European countries and in North America. Swedish Univ. of Agric. Sci., Dept. Soil Sci. Div. Soil Fert. Rep. 122: 1-80, 8 Tabl., 22 fig., 3 enclosures.

- 1981. Ammonium- och nitratkvävets rörelser och fördelning i marken II. Metoder för mineralkväveprovtagning och -analyser. Summary: Movement and distribution of ammonium- and nitrate$\mathrm{N}$ in the soil II. Methods of sampling and analysing mineral nitrogen. Swedish Univ. of Agric. Sci., Dept. Soil Sci., Div. Soil Fert. Rep. 137: 1-79, 8 Tabl., 32 Fig.

QUESNEL, H. J. \& LAVKULICH, L. M. 1980. Nutrient variability of forest floor near Port Hardy, British Columbia, Canada. Can. J. Soil. Sci. 60: 565-573.

RYTI, R. 1965. On the determination of soil pH. J. Scient. Agric. Soc. Finl. 37: 51-60.

SIPPOLA, J. \& TARES, T. 1978. The soluble content of mineral elements in cultivated Finnish soils. Acta Agric. Scand. Suppl. 20: 11-25.

SNEDECOR, G. W. 1948. Statistical methods. 485 p. 4th Ed., 3rd Print. Ames Iowa.

URVAS, L. \& JUSSILA, M. 1979. Rivilannoituksen vaikutus viljavuustutkimuksen tulokseen. Maatalouden tutkimuskeskus, Maantutkimuslaitoksen Tiedote 7: 1-10.

Ms received January 15, 1983 


\title{
Muokkauskerroksessa ominaisuuksien vaihtelevuus Suomenlahden rannikon pelloilla ja analyysejä varten tarvittavien näytteiden lu- kumäärä
}

\author{
Raili Jokinen \\ Helsingin yliopisto, Maanviljelyskemian laitos, 00710 Helsinki 71
}

Tutkimusta varten kerätiin syksyllä 1979 ja 1981 Helsingin yliopiston Viikin koetilan pelloilta kymmeltä lohkolta yhteensä 430 muokkauskerroksen näytettä. Lohkoille merkittiin näytteiden ottolinjat $40 \mathrm{~m}$ välein ja kullekin linjalle näytteiden ottopaikat $40 \mathrm{~m}$ välein. Hehtaaria kohti otettujen näytteiden määrä vaihteli 5.1-6.5.

Näytteistä analysoitiin raekoostumus, orgaanisen hiilen pitoisuus, $\mathrm{pH}\left(\mathrm{CaCl}_{2}\right)$, kasveille käyttökelpoinen fosfori (Bray 1 testillä), neutraalin ammoniumasetaatin vaihtamat kalsium, magnesium ja kalium, efektiivinen kationinvaihtokapasiteetti sekä $1 \mathrm{M}$ kaliumkloridiin uuttuvan aluminiumin ja vedyn summa. Ominaisuuksien vaihtelevuutta eri lohkojen välillä ja lohkojen sisällä tutkittiin variaatiokertoimen avulla. Analyysejä varten tarvittavien näytteiden lukumäärä laskettiin kahdella tulosten tarkkuuden tasolla: $\mathrm{n}_{1}=$ ankara tarkkuus (sallittu poikkeama $10 \%$ ) ja $\mathrm{n}_{2}=$ kohtalainen tarkkuus (sallittu poikkeama $25 \%$ ).

Kullakin lohkolla $\mathrm{pH}\left(\mathrm{CaCl}_{2}\right.$ )-luvun variaatiokertoimet olivat alhaiset (alle $10 \%$ ), vaikka $\mathrm{pH}\left(\mathrm{CaCl}_{2}\right)$ saattoi lohkon sisällä vaihdella 4.6-6.8 (taulukko 2 ja 3). Suurimmat kertoimen arvot yksittäisillä lohkoilla todettiin vaihtuvan magnesiumin pitoisuuden, efektiivisen kationinvaihtokapasiteetin ja $1 \mathrm{M}$ kaliumkloridiin uuttuvan aluminiumin ja vedyn summan analyysituloksissa. Eri ominaisuuksien vaihteluväli lohkojen sisällä oli laaja (taulukko 3).

Otettaessa maanäytteitä kenttäkokeita tai neuvontaa varten näytteiden lukumäärä tulisi ratkaista eniten vaihtelevan kulloinkin kyseeseen tulevan maan ominaisuuden perusteella. Näyttää siltä, että keskimäärin kahdeksan näytettä hehtaarilta tarvittaisiin maalajin (savenpitoisuus) ja orgaanisen hiilen pitoisuuden määrittämiseen, sekä 10-16 näytettä kasveille käyttökelpoisen fosforin tai vaihtuvien kationien pitoisuuden määrittämiseen ankarat vaatimukset täyttävällä tarkkuudella. Kohtalaisen tarkkuuden täyttävät analyysitulokset saataneen noin neljästä näytteestä hehtaarilta.

Tässä tutkimuksessa saadut näytteiden lukumäärää koskevat tulokset soveltunevat paremmin neuvonnan kuin tutkimuksen tarkoituksiin. Kenttäkokeista maanäytteitä tulisi ottaa hehtaaria kohti huomattavasti enemmän kuin edellä esitetyt tulokset osoittavat. Maatilan käyttöön tarkoitetuilla koneilla hoidettavien kenttäkokeiden suhteellisen suurilta ruuduilta otetut osanäytteet tulisi analysoida erikseen. 